\title{
USIA PERKAWINAN BERDASARKAN MENTAL EMOSIONAL ANTARA PRIA DAN WANITA
}

\author{
Ahlun Nazi Siregar \\ UIN Maulana Malik Ibrahim Malang \\ ahlunnazi@gmail.com
}

\begin{abstract}
This paper discusses the Age of Marriage Based on Mental and Emotional Aspects between Men and Women. It has been regulated in the law that a person only marries when he is 19 years old, either a man or a woman (Law Number 16 of 2019). The purpose of determining the minimum age limit for marriage is to maintain the health, physical, mental and emotional maturity of each party. This research uses the type of library research, as the main source is the law, articles, and related books. The purpose of this study is to analyze the suitability of the age of marriage with the mental and emotional aspects of men and women in dealing with marriage. This research shows that adolescents who are married under the age of 20 (twenty) years tend to be unstable in making decisions, solving every problem, because at that age most teenagers are still in school either as students or students who want to feel free and prefer is playing. But it does not rule out the implementation of a happy and eternal marriage if at the age of each party has been provided in-depth about matters relating to marriage. Ideally, marriage for men is 25-30 years old and for women is 20-25 years old.
\end{abstract}

Keywords: Gender, Emotional, Mental, Age of Marriage, Law Number 16 of 2019

\section{Abstrak}

Tulisan ini membahas tentang Usia Perkawinan Berdasarkan Mental Emosional Antara Pria dan Wanita. Telah diatur dalam Undang-Undang bahwa seseorang hanya diizinkan menikah ketika telah berusia 19 tahun baik pria maupun wanita (UU No.16 Tahun 2019). Tujuan dari penetapan batas minimal usia perkawinan tersebut adalah untuk menjaga Kesehatan, kematangan fisik, mental dan emosional dari masing-masing pihak. Penelitian ini menggunakan jenis penelitian kepustakaan library research, sebagai sumber utamanya adalah Undang-Undang, Artikel dan buku yang berkaitan. Adapun tujuan dari penelitian ini adalah untuk menganalisis tentang kesesuaian antara usia perkawinan dengan mental emosional antara pria dan wanita dalam menghadapi pernikahan. Penelitian ini menunjukkan bahwa remaja yang menikah di bawah umur 20 (dua puluh) tahun cenderung tidak stabil dalam mengambil keputusan, menyelesaikan setiap persoalan, disebabkan pada usia tersebut kebanyakan remaja masih berada di bangku sekolah baik sebagai mahasiswa maupun siswa yang lebih ingin merasa bebas dan lebih suka bermain. Namun tidak menutup kemungkinan terlaksananya 
pernikahan dengan bahagia dan kekal jika pada usia tersebut masing-masing pihak telah dibekali secara mendalam tentang hal-hal yang berkaitan tentang pernikahan. Idealnya pernikahan bagi pria adalah di usia 25-30 tahun dan bagi perempuan adalah di usia 20-25 tahun.

Kata Kunci: Gender, Emosional, Mental, Usia Perkawinan, UU No. 16 Tahun 2019

\section{PENDAHULUAN}

Dewasa ini kita mengetahui bahwa tingkat perceraian di indonesia semakin meningkat sepanjang tahun. Berbagai persoalan menjadi pemicu terjadinya tindakan perceraian. Salah satu penyebab perceraian itu adalah ketidaksiapan pasangan suami dan isteri dalam menghadapi bahtera rumah tangga (Alfa, 2019). Maka untuk menghadapi masalah tersebut pemerintah menerapkan aturan tentang batasan usia dalam pernikahan. Dengan batasan usia tersebut diharapkan pasangan suami-isteri mampu menjalani kehidupan rumah tangga dengan sikap dan psikologi yang matang sehingga dapat mengambil keputusan dengan sebaik-baiknya (Olivia, 2015).

Meskipun dalam hukum Islam sendiri tidak mengatur tentang batasan minimal usia seseorang untuk melangsungkan pernikahan akan tetapi para ulama berdasarkan kepada al-Qur'an dan Hadis memberikan patokan bahwa pernikahan dapat dilaksanakan jika seseorang tersebut sudah dewasa dan kedewasaan itu ditandai dengan ihtilam (mimpi dengan mengeluarkan air mani) bagi laki-laki dan haid bagi perempuan (Hikmah, dkk, 2020).

Islam tanpaknya lebih mengedepankan pada aspek kematangan fisik dan jiwa seseorang setelah memasuki usia baligh. Hal ini dilihat dari pembebanan hukum bagi seseorang yang sudah dianggap mukallaf (mampu menanggung beban hukum atau cakap hukum). Maka sudah diberikan izin untuk melaksanakan perkawinan. Sebagaimana yang terdapat pada sebuah hadis Rasulullah Shallallahu 'alaihi wa sallam yang artinya:

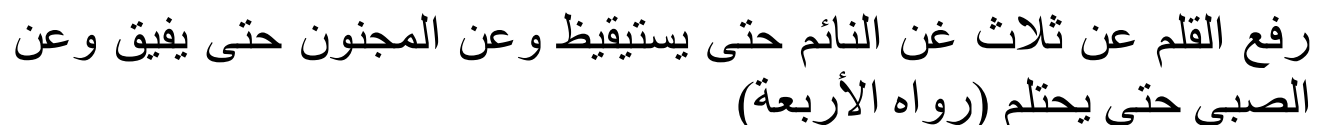

Artinya: Terangkat pertanggungjawaban seseorang dari tiga hal: orang yang tidur sampai ia bangun, orang yang gila hingga ia sembuh, dan anakanak hingga ia bermimpi. (Riwayat Imam Empat).

Isyarat yang terkandung dalam hadis di atas adalah bahwa kematangan seseorang dilihat dari pada gejala seksualitasnya, yaitu keluarnya sperma melalui mimpi/ ihtilam bagi laki-laki dan menstruasi/ haidh bagi perempuan. 
Berdasarkan segi usia, kematangan seksualitas masing-masing pada umumnya orang berbeda. Namun demikian hadis ini memberikan gambaran bahwa biasanya kematangan tersebut terjadi pada usia 15 (lima belas) tahun.

Hal ini didukung oleh hadis Riwayat Ibn Umar yang mengatakan (Shodikin, 2015):

"aku telah mengajukan diri kepada Rasulullah untuk ikut serta dalam perang uhud yang ketika itu usiaku 14 (empat belas) tahun, Rasul tidak mengizinkanku. Kemudian di kesempatan yang lain aku mengajukan diri lagi kepada Rasulullah tatkala perang Khandaq. Ketika itu usiaku 15 (lima belas) tahun, dan Rasul membolehkan diriku untuk mengikutinya.

Adapun bagi perempuan, diperbolehkan untuk menikahkannya di usia 6 (enam) tahun (belum baligh). Tindakan ini berdasarkan atas apa yang terjadi pada 'Aisyah ketika dinikahi oleh Rasulullah: Rasulullah menikahi 'Aisyah ketika usianya enam tahun, dan beliau menggaulinya Ketika ia berusia Sembilan tahun,, (Riwayat Muslim). Terdapat perbedaan pendapat tentang hadis ini Sebagian ulama memandang hadis ini adalah tindakan boleh dan sah untuk dilakukan, sebagaian ulama yang lain memandang bahwa hadis ini hanya sebagai khabar yang tidak diperintahkan untuk melaksanakan perkawinan pada usia 6 tahun (Shodikin, 2015).

Berdasarkan kepada hadis-hadis tersebut dapat dipahami bahwa tanda tanda dewasa (baligh)-nya seorang itu adalah telah sampainya usia 15 (lima belas) tahun bagi laki-laki dan 9 (Sembilan) tahun bagi wanita, kemudian telah bermimpi (ihtilam) yang mengeluarkan sperma bagi laki-laki dan haidh (menstruasi) bagi wanita (Rofiq, 2013). Secara definitif Islam tidak pernah memberikan batasan kedewasaan untuk menikah, yang menjadi patokannya adalah tentang perkembangan seseorang dari segi tingkat kemampuan dalam melaksanakan hukum (ahliyyah al-wujud wa al-ada). Usia pernikahan menurut Islam dilihat kepada dua fase yaitu fase baligh dan rusyd (Rofiq, 2013).

Dilihat dari Undang-Undang Perkawinan No.1 Tahun 1974 Pasal 7 ayat (1) dinyatakan bahwa perkawinan hanya diizinkan bila pihak pria sudah mencapai usia 19 (Sembilan belas) tahun dan wanita telah berusia 16 (enam belas) tahun. Namun kemudian terjadi perubahan peraturan pada tahun 2019 tentang usia perkawinan dan telah disahkan, adapun perubahan terhadap isi dari Undang-Undang tersebut adalah perkawinan hanya diizinkan apabila pria dan wanita sudah mencapai usia 19 (sembilan belas) tahun. Adapun tujuan dari perubahan ini tutur Yohana Susana Yambise Menteri Pemberdayaan Perempuan dan Perlindungan anak tahun 2019 
adalah untuk melindungi hak-hak anak agar terciptanya perkawinan dan rumah tangga yang sehat dan sejahtera (Hikmah, dkk, 2020).

Batasan usia pernikahan ini merupakan salah satu aturan yang diterapkan diseluruh negara, tujuannya adalah untuk mempersiapkan pasangan yang akan melangsungkan pernikahan agar mampu menjalankan kehidupan rumah tangganya dengan penuh keharmonisan, kebahagiaan serta rasa tanggung jawab yang besar terhadap keluarganya. Di samping itu terdapat beberapa alasan yang menyebabkan adanya penerapan batas usia pernikahan diantaranya adalah masalah kependudukan disetiap negara, bahwa usia yang masih muda bagi seorang wanita untuk menikah, akan berakibat pada meningkatnya laju kelahiran dan pertumbuhan penduduk. Kemudian tentang kesiapan fisik dan jiwa seseorang dalam hal ini ditujukan pada pembebanan hukum (taklif) (Rofiq, 2013). Paling utama adalah terciptanya keluarga yang bahagia dan kekal (hanya kematian yang memisahkan pernikahannya) jauh dari kata perceraian.

Tentunya usia pernikahan sangat bepengaruh terhadap keharmonisan rumah tangga, kesiapan mental dan emosional baik dari pihak pria dan wanita sangat diperlukan, maka dari itu penulis akan membahas tentang usia perkawinan berdasarkan kepada mental dan emosional antara pria dan wanita.

\section{METODE}

Penelitan ini menggunakan jenis penelitian kepustakaan library research, sebagai sumber utamanya adalah Undang-Undang, Artikel dan buku yang berkaitan. Undang-udangan yang dikaji adalah Undang-undang No 16 Tahun 2019 tentang perubahan atas Undang-undang No 1 tahun 1974 tentang Perkawinan. Serta artikel dan buku yang dimaksud adalah jurnaljurnal penelitian dan buku-buku yang memiliki relevansi dengan tujuan penelitian ini.

\section{HASIL PENELITIAN DAN PEMBAHASAN \\ Usia Perkawinan Menurut Hukum Islam}

Secara terperinci agam Islam tidak membahas tentang batas minimal usia perkawinan, dikarenakan tidak adanya ayat al-Qur'an dan hadis yang menunjukkan minimal usia pernikahan bahkan dalam kitab-kitab fikih juga tidak dibicarakan. Hukum Islam mengizinkan terlaksananya pernikahan pada usia yang dikategorikan sebagai anak-anak, kebolehan tersebut karena tidak adanya larangan untuk melaksanakan pernikahan di usia tersebut. Kemudian merujuk kepada khabar dari 'Aisyah yang dinikahi oleh Rasulullah shallallahu 
'alaihi wa sallam pada saat berusia 6 (enam) tahun dan menggaulinya setelah berusia 9 (Sembilan) tahun (Syarifuddin, 2006).

Tidak adanya ketentuan dalam agama Islam tentang batas usia minimal dan maksimal bagi pasangan yanga akan melangsungkan perkawinan maka dapat dipahami bahwa agama memberikan kelonggaran kepada setiap individu untuk mengaturnya sendiri, hanya saya al-Qur'an dan hadis memberikan isyarat bahwa setiap individu yang akan melangsungkan pernikahan harus didasari atas kemampuan baik secara fisik, mental dan materi sebagai pendukung tercapainnya tujuan dari pada pernikahan tersebut. Adapun isyarat ini terdapat dalam surah an-Nuur ayat 32 yang berbunyi:

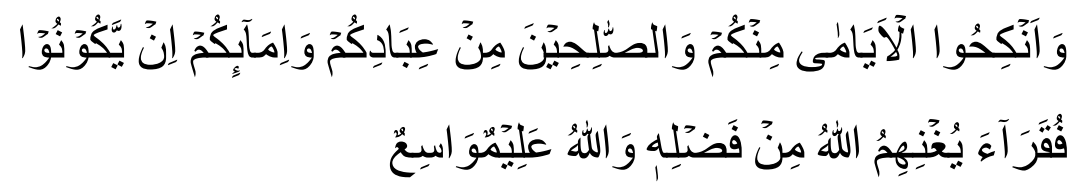

Artinya: Dan kawinkanlah orang-orang yang sendirian di antara kamu dan orang-orang yang sudah layak (berkawin) dari hambahamba sahayamu yang laki-laki maupun yang perempuan. Jika mereka miskin, Allah akan mampukan mereka dengan segala karunia-Nya. Allah Maha Luas (pemberian-Nya) lagi Maha Mengetahui.

Kata ( الصالحين yang terdapat pada ayat diatas dipahami oleh banyak Ulama sebagai orang yang mampu (layak) secara mental, emosional dan spiritual dalam melaksanakan perkawinan dan membina rumah tangga secara baik dan benar (Shihab, 2005). Begitu juga dengan hadis Rasulullah yang memerintahkan kepada para pemuda yang sudah memiliki kemampuan untuk segera melangsungkan perkawinan (Muslim, 2003). Adapun bunyi hadis sebagai berikut:

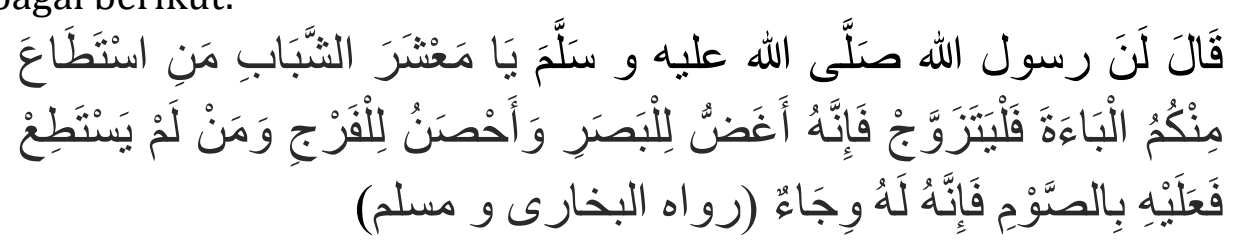

Artinya: wahai generasi muda, barang siapa diantara kamu memiliki kemampuan untuk melangsunkan pernikahan (berkeluarga) hendaknya ia kawin, karena dengan itu ia dapat menundukkan pandangannya dan memelihara kemaluannya dan barang siapa yang belum mampu hendaknya berpuasa, sebab dengan itu akan dapat mengendalikanmu / menjadi perisai bagimu.

Berdasarkan keterangan yang disampaikan dalam ayat al-Qur'an dan Hadis diatas dapat dipahami bahwa terdapat isyarat yang menunjukkan 
pernikahan itu dapat dilaksanakan jika telah merasa mampu dan dewasa (menjaga diri dan mengendalikan emosional). Seseorang dianggap dewasa dalam kajian fiqh adalah dengan adanya tanda-tanda yang bersifat jasmani yaitu baligh yang secara umum ditandai dengan beberapa hal diantaranya, sempurnanya umur 15 (lima belas) tahun dan telah mengalami ihtilah (mimpi) bagi pria, dan bagi wanita ditandai dengan datangnya haidh (mentruasi) yang pada umumnya terjadi minimal diusia 9 (sembilan) tahun (Al-Hadhramy, 1994).

Para Ulama Mazhab sepakat bahwa jika telah datang haidh merupakan bukti ke baligh-an bagi seorang wanita. Karena haidh-nya seorang perempuan sama kedudukannya dengan ihtilam bagi laki-laki. Alat reproduksi wanita ketika sudah mengalami haidh akan siap untuk menjalani proses kehamilan. Terjadinya kehamilan tersebut disebabkab adanya pembuahan ovum oleh sperma. Selain tanda-tanda yang telah disebutkan para Ulama Mazhab juga mengatakan bahwa tumbuhnya bulu dibagian ketiak merupakan bukti baligh-nya seseorang (Mughniyah, 2001).

Terdapat perbedaan pendapat di kalangan ulama mengenai batas usia baligh-nya seseorang, Imam Hanafi mengatakan bahwa usia maksimal balighnya seseorang adalah 18 (delapan belas) tahun laki-laki dan 17 (tujuh belas) tahun perempuan. Imam Malik mengatakan bahwa baligh ditandai dengan keluarnya sperma secara mutlak dalam kondisi tertidur ataupun menghayal, atau ditandai dengan tumbuhnya rambut di anggota tubuh, Imam Malik tidak menetapkan batas usia minimal dan maksimal. Imam Syafi'I mengatakan bahwa batasan baligh adalah 15 (lima belas) tahun bagi laki-laki dan 9 (Sembilan) tahun bagi perempuan. Imam Ahmad berpendapat bahwa baligh bagi laki-laki ditandai dengan mimpi atau sudah berusia 15 (lima belas) tahun sedangkan bagi perempuan ditandai dengan haidh (Arori, 2015).

Secara umum syarat dari pernikahan menurut Hukum Islam adalah adanya kemampuan dan sikap kedewasaan antara kedua belah pihak (calon suami dan isteri) tanpa adanya rincian yang jelas dan tegas tentang batasan usia kedewasaan tersebut untuk melaksanakan perkawinan (Mughniyah, 2001). Ibnu Syubrumah, Abu bakar al-Asham, dan Utsman al-Batti berpendapat bahwasanya laki-laki ataupun perempuan tidak bisa menikah atau dinikahkan sebelum mereka telah mencapai usia baligh dan atas dasar persetujuan dari masing-masing anak yanag akan dinikahkan tersebut (Husein, 2007). Adapun dasar hukum yang menjadi pegangannya adalah alQur'an surah an-Nisaa' ayat 6, yang berbunyi:

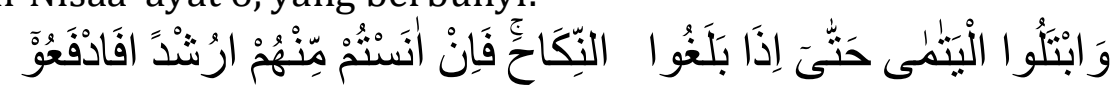




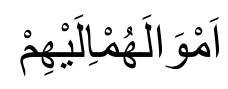

Artinya: Dan ujilah anakyatim itu sampai mereka cukup umur untuk kawin. kemudian jika menurut pendapatmu mereka telah cerdas (pandai memelihara harta), Maka serahkanlah kepada mereka harta-hartanya.

Wahbah Zuhailiy memberikan penjelasan tentang kalimat (حَنِّن (حَ) yaitu telah sampainya seseorang pada ambang batas usia untuk melaksanakan perkawinan, ditandai dengan telah terjadinya ihtilam (mimpi) pada seorang laki-laki dan pada saat itu juga telah dibebani perkara-perkara taklif. Sama hal nya dengan wanita akan dibebankan pekara taklif ketika telah terjadi hadih (menstruasi) pada dirinya (Zuhaily, 2005).

Berdasarkan keterangan yang terdapat dalam konteks al-Qur'an, dan hadis serta penafisiran yang disajikan oleh para ulama, terlihat bahwa terjadi perbedaan pandangan seputar kedewasaan yang bersumber dari kalimat telah dewasa (rusyd) dan mimpi (ihtilam). Namun pada kenyataan di lapangan bahwa kedewasaan sendiri tergolong tidak pasti (ambigu), sebab seringkali definisi pada kata rusyd tidak sesuai dengan usia seseorang. Banyak terlihat di dalam masyarakat seseorang yang sudah tergolong dewasa dari segi umur, namun tindakan dan perilakunya tidak mencerminkan kedewasaan usianya. Padahal dari segi biologis tanda-tanda kedewasaannya telah nampak jelas (Adhim, 2003).

Imam al-Ghazali memberikan penekanan terhadap pernikahan yang akan dilaksanakan haruslah oleh calon suami-istri yang sudah baligh, tanpa melihat secara jelas usia dari masing-masing calon, akan tetapi memberikan batasan baligh yang ditandai dengan ihtilam untuk laki-laki dan haidh untuk perempuan serta tumbuhnya bulu di area ketiak laki-laki dan perempuan (Mughniyah, 2001). Oleh karena itu dapat diketahui bahwa kedewasaan seseorang secara biologis biasanya dapat ditentukan dengan ditemukannya tanda-tanda seperti telah ihtilam (mimpi) bagi pria, haidh bagi wanita, kerasnya suara, tumbuhnya bulu dibagian ketiak dan tumbuhnya bulu kasar di sekitar kemaluan (Al-Jaziriy, 1982).

\section{Usia Pernikahan Menurut Hukum Positif}

Undang-Undang Perkawinan No.1 Tahun 1974 sebagai pedoman dalam melaksakan perkawinan memliki beberapa prinsip atau asas yang merujuk kepada tujuan dari pernikahan, yakni sebagai wadah untuk membentuk keluarga (rumah tangga) yang bahagia, kekal dan sejahtera. Untuk itu 
diperlukan kesiapan fisik, mental dan emosional yang matang agar dapat saling melengkapi dan mengembangkan kepribadiannya guna mencapai kesejahteraan jasmani dan rohani (Olivia, 2015).

Salah satu upaya yang dilakukan oleh pemerintah untuk merealisasikan tujuan daripada pernikahan itu sendiri adalah dengan menerapkan batasan usia bagi masing-masing mempelai yang tertuang dalam Undang-Undang Perkawinan No.1 Tahun 1974 terdapat pada pasal 7 ayat (1), yang berbunyi:

"Perkawinan hanya diizinkan jika pihak pria sudah mencapai umur 19 (Sembilan belas) tahun dan pihak wanita sudah mencapai umur 16 (enam belas) tahun" dan ayat juga (2) menyebutkan "Jika belum mencapai umur yang sudah ditetapkan pada ayat (1) maka dapat mengajukan/meminta dispensasi perkawinan kepada Pengadilan setempat atau pejabat yang berwenang yang ditunjuk oleh kedua orang tua pihak pria maupun pihak wanita.

Pasal di atas menjadi dasar hukum bahwa anak perempuan yang sudah berumur 16 (enam belas) tahun dapat dinikahkan. Kemudian jika melihat pada ayat (2) dari pasal tersebut dapat kita pahami bahwa batas usia minimum anak perempuan yang telah diatur dalam ayat (1) tidaklah bersifat mutlak, sebab masih ada jalan yang dapat dilalui jika anak tersebut belum mencapai usia 16 tahun. Akibatnya sering kita temui anak-anakyang berusia dibawah 16 tahun sudah menjalani pernikahan atas izin dari orangtuanya yang diketahui oleh pengadilan atau pejabat setempat (Christian dan Edenela, 2019).

Seiring berjalannya waktu telah terjadi perubahan atau revisi terhadap Undang-Undang Perkawinan No.1 Tahun 1974 pasal 7 ayat (1) yang awalnya perkawinan hanya diizinkan jika pihak pria telah mencapai usia 19 (sembilan belas) tahun dan wanita sudah mencapi usia 16 (enam belas) tahun. Kemudian dirubah oleh Undang-Undang No. 16 Tahun 2019 yang berbunyi Perkawinan hanya diizinkan apabila pria dan wanita sama-sama telah mencapi usia 19 (Sembilan belas) tahun".

Perubahan atas aturan tersebut bukan tanpa alasan, melainkan banyaknya pertimbangan, salah satunya tertuang dalam konsiderans Undang-undag No. 16 Tahun 2019 yaitu perkawinan pada usia anak menimbulkan dampak negatif terhadap tumbuh kembang anak, melindungi dari tindakan kekerasan dan diskriminasi, menjaga Kesehatan anak serta kedewasaan dan mentalitas anak ketika telah memasuki kehidupan berumah tangga (Pitrotussaadah dan Mintarsih, 2020).

Adapun Syarat-Syarat Perkawinan Menurut KUHPerdata terdiri dari beberapa perkara, yang pertama adalah Sepakat yang diatur dalam pasal 28 
KUHPerdata. Kata sepakat tersebut harus dinyatakan langsung oleh pihak pria dan wanita tanpa adanya tekanan atau paksaan dari pihak manapun. Kemudian yang kedua adalah batas usia, yang telah diatur dalam Pasal 29 KUHPerdata yang menentukan batas umur buat seseorang yang akan melangsungkan suatu perkawinan yaitu 18 (delapan belas) tahun untuk lakilaki dan 15 (lima belas) tahun untuk perempuan kecuali bila diberikan dispensasi oleh pemerintah berdasarkan alasan-alasan yang sangat penting dan mendesak maka pernikahan dapat dilakukan sebelum mencapai batas usia yang telah ditentukan (Olivia, 1974).

Sedangkan ketentuan formal pendewasaan dalam KUHPerdata adalah ketika berusia 21 (dua puluh satu) tahun sebagai usia perkawinan yang ideal. Seseorang yang telah dewasa dianggap mampu berbuat karena memiliki daya yuridis atas kehendaknya sehingga dapat menentukan perbuatannya berdasarkan keadaan hukum pada dirinya sendiri. Walupun demikian tidak dilarang menikah ketika berusia 18 (delapan belas) tahun bagi laki-laki dan 15 (lima belas) tahun bagi perempuan (Pitrotussaadah dan Mintarsih, 2020).

\section{Mental Emosional Pria dan Wanita Berdasarkan Usia Perkawinan}

Tujuan dari sebuah perkawinan adalah untuk membentuk keluarga (rumah tangga) yang bahagia dan kekal berdasarkan Ketuhanan Yang Maha Esa. Maka untuk meraih tujuan tersebut perlu adanya persiapan yang matang baik dari usia, pengetahuan tentang pernikahan, fisik, mental dan emosional dari masing-masing pasangan. Untuk itu akan dibahas lebih dalam mengenai beberapa hal yang telah disebutkan diantaranya:

a. Ditinjau Dari Segi Usia

Menurut Glick dan Norton (1977) Perkawinan yang dilakukan remaja belasan tahun cenderung berpeluang terjadi perceraian dua kali lebih besar dibandingkan laki-laki dan wanita yang menikah pada usia 20 tahunan. Sedangkan bagi laki-laki usia berpengaruh terhadap perceraian. Berdasarkan hasil penelitian menyatakan bahwa perceraian lebih banyak terjadi pada pasangan yang menikah muda, yaitu ketika laki-laki (suami) tersebut berusia dibawah 25 tahun (Suryaningrum, 2019).

\section{b. Ditinjau Dari Segi Psikologis}

Dalam ilmu psikologi istilah remaja atau adolescence yang berarti tumbuh atau tumbuh menjadi dewasa, istilah adolescence memiliki cakupan yang luas, berkaitan dengan kematangan mental, emosional, social, dan fisik. Menentukan usia perkawinan berdasarkan adolescence adalah dengan 
melihat kepada tahapan pertumbuhan dari masa anak-anak menuju masa dewasa. Penetapan masa usia remaja ini sulit untuk ditentukan, namun pada umumnya para ahli menggunakan usia antara 12 (dua belas) hingga 21 (dua puluh satu) tahun. Rentang waktu usia remaja ini biasanya dibedakan atas tiga, yaitu 12-15 tahun adalah masa remaja awal, 15-18 tahun adalah masa remaja pertengahan, dan 18-21 tahun adalah masa remaja akhir (Pitrotussaadah dan Mintarsih, 2020).

Ketidakstbilan emosi pada usia remaja akan berdampak pada terjadinya kekerasan dalam rumah tangga (KDRT). Usia merupakan salah satu factor yang mempengaruhi kematangan emosional pada usia remaja terjadi masa transisi dari masa anak-anak beralih ke masa dewasa yang diawali dengan puberetas. Disamping itu juga terjadi proses kematangan social dan emosional.

Menurut sutriyatmi pada usia remaja 16 (enam belas) tahun secara psikologi mereka masih berkembang, secara kesehatan reproduksi juga masih dalam proses perkembangan sesungguhnya belum siap untuk melakukan hubungan seksual apalagi untuk hamil dan melahirkan. Dokter Kartono Mohamad mengatakan bahwa secara global kehamilan dan melahirkan pada usia remaja 15-19 tahun cenderung menyebabkan terjadinya kematian. Bahkan kehamilan usia remaja meningkatkan kematian untuk ibu dan janinnya (Rahmawati, 2020).

c. Ditinjau Dari Pertumbuhan Fisik

Merujuk kepada ketentuan Agama Islam bahwa kematangan fisik seseorang merupakan sesuatu aspek yang paling menonjol. Hal ini dapat dilihat dari pembebanan hukum (taklif) yang disebut mukallaf yaitu orang yang sudah mampu menanggung beban hukum atau cakap hukum. Kematangan seseorang dilihat pada gejala kematangan seksualitasnya. Seorang pria sudah dianggap matang fisiknya jika telah keluar mani melalui mimpi (baligh) dan perempuan sudah menstruasi (haidl) dalam kondisi ini reproduksi perempuan sudah bisa mengalami kehamilan (Rofiq, 2003).

d. Ditinjau Dari Mental Emosional

Pada usia yang telah ditetapkan oleh Undang-Undang Perkawinan Pasal 7 ayat (1) bahwa perkawinan hanya diizinkan ketika pria telah mencapai usia 19 (Sembilan belas) tahun dan wanita 16 (enam belas) tahun, yang kemudian di rumah peraturan tersebut melalui Undang-Undan No. 16 Tahun 2019 yang menyatakan bahwa perkawinan hanya diizinkan jika pria dan wanita sudah mencapai usia 19 (Sembilan belas) tahun.

Berdasarkan kepada usia tersebut kebanyakan dari pria dan wanita masih menjalani proses Pendidikan baik itu sebagai Mahasiswa ataupun 
sebagai Siswa. Undang-Undang Perlindungan Anak (UUPA) No.35 tahun 2014 mengatakan bahwa orang tua berkewajiban dan bertanggung jawab untuk mencegah terjadinya perkawinan pada usia anak. Dikategorikan sebagai anak adalah mereka yang belum berusia 18 (delapan belas) tahun sesuai dengan ketentuan pasal 1 butir 1 UUPA (Christian dan Edenela, 2019).

Mental emosional pada usia tersebut cenderung tidak dapat terkendali karena pada masa itu adalah masa transisi dari remaja menuju dewasa. Sering kali remaja pada usia 15-19 tahun mencari kebahagian sendiri, bermain bersama teman-teman dan narcistic yaitu mencintai dirinya sendiri, suka dengan teman-teman yang memiliki sifat yang sama atau serupa dengannya, dan bersifat labil atau berubah-ubah tidak konsisten atau plinplan, mudah terpengaruh oleh lingkungan dan hal-hal baru yang dialaminya. Kemudian ketika berusia 20 tahun ke atas maka emosi, minat, konsentrasi dan cara berfikir mulai stabil. Kemampuan untuk menyelesaikan permasalahan sudah mulai meningkat, pemahaman terhadap suatu peristiwa serta rasa tanggung jawab pun semakin meningkat (Haryanti, 2016).

Berdasarkan atas uraian yang telah disampaikan di atas berkaitan dengan usia perkawinan menurut hukum Islam dan hukum Positif terdapat persamaan dan perbedaan. Persamaannya adalah terletak pada kesiapan mental, fisik, psikologi dan kemampuan materi. Hukum Islam dan Hukum Positif sangat mengedepankan tentang kesiapan dari masing-masing pihak pria dan wanita baik eksternal maupun internal ketika akan berumah tangga. Sedangkan perbedaannya terletak pada batas usia minimal terlaksananya pernikahan. Dalam agama Islam tidak terdapat uraian yang eksplisit tentang minimal usia pernikahan, yang menjadi petunjuk adalah ketika seorang pria dan wanita sudah memasuki usia baligh yang secara usia setiap individu berbeda-beda. Sedangkan Undang-Undang Perkawinan mengatur tentang usia pernikahan yaitu minimal usia pernikahan adalah ketika sudah mencapi usia 19 (Sembilan belas) tahun bagi pria dan wanita (UU N0. 16 Tahun 2019).

Secara mental psikologi bagi remaja yang berusia di bawah 20 (dua puluh) tahun cenderung tidak stabil, belum dianggap mampu dalam mengambil keputusan yang tepat bagi dirinya, belum dapat sepenuhnya menanggung beban tanggung jawab mengurus kehidupan rumah tangga yang semestinya adalah untuk orang yang sudah cukup umur atau dewasa. Disamping itu akan menimbulkan efek negative jika terlaksananya pernikahan pada usia tersebut, diantaranya terbatasnya pergaulan dan berkurangnya bahkan hilangnya masa bermain dengan teman sebayanya yang berimbas kepada perkembangan mental dan emosional (Olivia, 1974). Namun tidak menutup kemungkinan rumah tangga akan Bahagia jika 
pernikahan pada usia 18-20 tahun dibekali dengan pembekalan yang sangat mendalam oleh orang tua atapun pejabat setempat dan didukung oleh tekad dan kesiapan yang kuat dari masing-masing pasangan. Tidak hanya sekedar merasa sudah dianggap dewasa baik dari hukum Islam maupun hukum positif kemudian melaksanakan pernikahan tanpa adanya pembekalan.

Kematangan emosi merupakan salah satu elemen yang sangat mendukung dalam sebuah pernikahan. Dimana laki-laki dan perempuan dapat menyelesaikan masalah-masalah yang ada dalam keluarganya, aspek dalam kematangan emosional adalah kemandirian yang mampu mengambil keputusan dengan tepat dan juga dapat bertanggung jawab atas keputusan yang diambilnya. Usia masing-masing calon pengantin merupakan bagian dari timbulnya rasa kemandirian, semakin bertambah usia seseorang maka semakin mampu pula dalam menngendalikan emosinya. Untuk itu pernikahan yang ideal berdasarkan Informasi yang diberikan oleh Badan Kependudukan dan Keluarga Berencana Nasional (BKKBN) adalah 20-35 tahun untuk perempuan dan 25-40 tahun untuk pria (Fahreza dan Nurwati, 2020).

\section{KESIMPULAN}

Usia perkawinan sebagaimana yang telah ditentukan oleh Hukum Islam dan Undang-undang Perkawinan tidak dapat dikatakan ideal untuk melaksanakan pernikahan, hal ini disebabkan masih terdapat tumpang tindih dengan peraturan-peraturan yang lain seperti dalam UUPA, kemudian dari segi mental dan emosional belum dapat dikatakan stabil dan matang. Maka alangkah baiknya pernikahan tersebut dilakukan ketika sudah berusia 20 tahun ke atas yang pada usia tersebut seseorang sudah dapat dikatakan dewasa dan mampu mengendalikan emosi serta memiliki rasa tanggung jawab yang meningkat.

\section{DAFTAR PUSTAKA}

Abdur ar-Rahman al-Jaziriy. Kitab al-Fiqh al-Madzahib al-Arba'ah. Beirut: Dar al-Fikr, 1982.

Achmad Asrori. "Batas Usia Perkawinan Menurut Fukaha Dan Penerapannya Dalam Undang-Undang Perkawinan di Dunia Islam.” Al-'Ada;ah 4 (Desember 2015). 
Ahmad Rofiq. Hukum Perdata Islam di Indonesia. Jakarta: Rajawalai Pers, 2013.

Al Hadhrami, Salim Bin Smeer. Safinatun Najah, terj. Abdul Kadir Aljufri, Surabaya: Mutiara Ilmu, 1994.

Alfa, Fathur Rahman. "Pernikahan Dini dan Perceraian di Indonesia." JAS: Jurnal Ilmiah Ahwal Syakhshiyyah 1 (Tahun 2019).

Amir Syarifuddin. Hukum Pekawinan Islam di Indonesia. Jakarta: Kencana, 2006.

Departemen Agama RI. Al-Qur'an dan Terjemah. Jakarta: Roudhatul Jannah, 2009.

Dwi Haryanti, Elza Mega Pamela, Yulia Susanti. "Perkembangan Mental Emosional Remaja Di Panti Asuhan." Jurnal Keperawatan Jiwa 4, no. 2 (November 2016): 97-104.

Fitria Olivia. "Batasan Umur Dalam Perkawinan Berdasarkan Undang-Undang Nomor 1 Tahun 1974.” Lex Jurnalica 12 (Desember 2015).

Imam Muslim. Shahih Muslim. Beirut: Darul Kutub Al-Ilmiah, 2003.

Jordy Herry Christian dan Kirana Edenela. "Terampasnya Hak-Hak Perempuan Akibat Diskriminasi Batas Usia Perkawinan." Lex Scientia 3, no. 1 (2019): 1-14.

M. Quraish Shihab. Tafsir al-Misbah. IV. Vol. IX. Jakarta: Lentera Hati, 2005.

Mohammad Fauzil Adhim. Kupinang Kau Dengan Hamdalah. Yogyakarta: Mitra Pustaka, 2003.

Muhammad Fahrezi dan Nunung Nurwati. "Pengaruh Perkawinan Dibawah Umur Terhadap Tingkat Perceraian." Prosiding Penelitian \& Pengabdian Kepada Masyarakat 7, no. 1 (April 2020): 80-89.

Muhammad Husein. Fiqh Perempuan. Yogyakarta: PT. Lkis Pelangi Aksara, 2007.

Muhammad Jawad Mughniyah. Fiqih Lima Madzhab. Jakarta: Lentera, 2001.

Nugrahayu Suryaningrum. "Determinan Perceraian di Jakarta Timur Tahun 2014 (Studi Data Pengadilan Agama dan Pengadilan Negeri)." Forum Ilmu Sosial 2 (Desember 2019): 128-41. 
Nur hukmah, Ach. Faisol, Dzulfikar Rodafi. "Batas Usia Pernikahan Dalam Perspektif Hukum Islam Dan Hukum Positif." Hikmatina 2 (2020).

Pitrotussaadah dan Mimin Mintarsih. "Batas Usia Minimal Perkawinan Menurut Hukum Positif di Indonesia dan Hukum Islam." Muttaqien 1, no. 1 (2020): 78-90.

Shodikin, Akhmad. "Pandangan Hukum Islam Dan Hukum Nasional Tentang Batas Usia Perkawinan." Mahkamah 9 (2015): 11.

Rahmawati, S. (2020). Batas Usia Minimal Pernikahan (Studi Komparatif Hukum Islam dan Hukum Positif). Syakhsia: Jurnal Hukum Perdata Islam, 21(1), 85-110.

Undang-Undang Republik Indonesia Nomor 1 Tahun 1974 tentang Perkawinan \& Kompilasi Hukum Islam. Bandung: Citra Umbara, 2012.

Wahbah az-Zuhaily. Tafsir al-Manar. III. Damaskus: Dar al-Fikr, 2005. 